Symbolically, the function occurred in Melbourne, one of the nation's two large industrial and financial capitals; the foundation Fellowship was of 64 men and two women. The earlier rift with the Academy of Science was healed, and cooperation was ensured by the presence of 12 Fellows of the Australian Academy of Science. Criteria for election to Fellowship of the new Academy emphasise innovation, but giving to the achievements of its Fellows a collective, collegiate character is a challenge the Academy has not yet solved.

The "suitable safeguards" surrounding government or industrial documents which involve public reticence on the part of its Fellows put the applied Academy at something of a disadvantage in the public prestige stakes when compared with the freer Academy of Science. The technologists have one potential advantage in coming largely from well-heeled industries which should need little persuading to fork out financial support. But a year-anda-half after inauguration, the new Academy is still walking along rather than jogging. In its first eight months of operation to mid-1976, it spent a mere $\$ 4,000$. It now maintains a parttime office in Melbourne, but is run on a spare-time basis by busy men. It badly needs to establish a permanent secretariat to service its present needs and future ambitions.

\section{Sorry, for copyright reasons some images on this page may not be available online}

\section{AAS's igloo}

These ambitions are presently centred on the promotion of innovation in industry and government, and on the mounting of a series of annual conferences on the general theme of "Energy and Resources to 2000". The first of these, scheduled for later this year, is on "Fuel and Energy Resources", followed by "Water and Land Resources" in 1978, "Mineral Resources" in 1979, and "Marine Resources" in 1980. And of course a start has been made in publishing the first results of a review of innovative technological achievement in Australia.

One hundred years ago this year, Australia's first industrially successful innovation was registered-the stumpjump plough. It opened up vast tracts of otherwise useless land to cultivation. This year sees a number of internationally competitive innovations beginning to get public recognition. Successful developments, such as the compact Self-Twist Spinning Machine, the Sirotherm process for desalination by thermally regenerated resins, and the Interscan system for aircraft landing control in three dimensions, may begin to persuade government and industry alike that the two Academies are speaking economic sense when they urge more active support for locally based R\&D.

\title{
Making paper work
}

\section{Christine Thomas explains the advantages in using recycled and mechanical pulp papers}

$\mathrm{F}$ EW people are aware, when they purchase good quality writing paper in preference to rougher note paper, or choose extra-soft toilet tissue rather than lower quality crepe tissue paper, that they are contributing to increasing environmental pollution. But investigation of the demand upon resources and the polluting effects of specific processes involved in paper production highlights the considerable differences in the environmental impact of different papers. The general picture that emerges is that the higher the quality of the paper produced, the greater the resource demand and pollution load created.

Paper consists of a network of fibrillated cellulose fibres bonded together by their gelatinous surfaces.

Christine Thomas, author of The Paper Chain, is a researcher at Earth Resources Research $L_{t d}$. London
The fibres are released from their plant structure during pulping, which for timber can be either by chemical or mechanical means. Chemical pulping methods use chemical solutions to dissolve away part of the plant structure, leaving the cellulose fibres whole and separated with minimum physical damage. Chemical pulp-based papers are considered for many purposes to be superior in quality to mechanical pulpbased papers. Mechanical pulps are generally weaker than chemical pulps and suffer from colour darkening.

Mechanical pulp papers, however, are of adequate quality for many uses, including newsprint, low grade printing papers, fibreboard, wrapping papers, and some tissues. And mechanical pulping provides a more efficient use of timber with a $90-95 \%$ yield of pulp from cut, dried wood compared to $40-65 \%$ for chemical pulping. Put another way, where it takes on average 13 trees to produce a tonne of chemical pulp, only six would be needed for mechanical pulp. And it is not only the resource demands of chemical pulp which are greater. Its production also creates a significantly more polluting effluent, and consumes more water than does mechanical pulping (see Table 1).

Waste paper can be recycled by repulping and releasing the cellulose fibres from their existing network to allow them to be reformed into a new sheet. Naturally the substitution of recycled papers for those containing virgin pulp will result in a reduction in demand for wood pulp, and will lessen the problems of solid waste disposal. In addition, however, it will result in a reduction of energy demand, of the order of $50 \%$ of the energy required for the wood pulping process. It may also lead to less overall pollution, and a saving in water (see Table 2).

Recycled papers themselves vary considerably. Because the fibres have previously been prepared for papermaking, the recycling process in theory is simpler than pulping wood. In practice, though, there are complications introduced by the presence of ink and 
contraries in the waste paper and by fibre damage due to repeated pulping. The highest grades of waste paper will produce high quality recycled papers with little or no upgrading and will create little environmental impact.

Most waste paper potentially available for recycling, however, requires some upgrading, and here the final product's quality becomes particularly relevant to the environmental impact. A bright, relatively high quality paper, made from low grade waste paper and requiring the fibres to be deinked, will consume more energy and water and will create more pollution than a lower quality paper produced from the same waste furnish. Hence, although an increase in recycling will reduce the overall environmental impact of paper manufacture, this neduction will be smaller if present high quality standards are maintained.

\section{Encouraging recycling}

How might attitudes towards paper quality be changed to encourage preferential use of recycled and mechanical pulp papers? The paper industry's resistance to using recycled fibres in some products is partly due to the resultant reduction in quality, which they maintain would not be acceptable to consumers. Whether the consumer or the paper industry needs reeducating, the government could take a positive lead by issuing advice and directives on paper quality standards to its stationery office, to local government and to government departments. This would both encourage a change in attitudes to paper quality and stimulate demand for recycled papers, thereby helping the paper industry to use more waste paper in more of its products.

Such a move could not be expected on environmental grounds alone; but there are strong economic reasons for recycling more waste paper. In 1974 Britain consumed 8.7 million tonnes of paper and board products, of which $47 \%$ was imported. Of the remaining 4.6 million tonnes produced in Britain, $45 \%$ of the furnish was from imported wood pulp. These pulp and paper imponts cost Britain over $£ 1,000$ million in that year.

The British paper and board industry's heavy reliance on imported wood pulp puts it at a considerable competitive disadvantage to integrated pulp and paper industries abroad, and this has resulted in increasing dependence on imports of finished goods. In $1960,77 \%$ of all paper and board consumed in Britain was home produced, but by 1974 this figure had dropped to $53 \%$. The industry has suffered contraction and decline. Since 1965 over 30 mills have closed and employment in the industry has dropped by about one-third.

In the face of economic necessity the paper industry is slowly increasing its capacity to recycle. There are considerable obstacles facing a significant increase in waste paper use. Acceptance of lower quality is only one. Plant modifications and availability of waste paper supplies are equally, if not more, important problems to overcome. The government, recognising the former problem, allocated last June $£ 23$ million for grant aid towards capital investment for increasing the use of indigenous fibres. With only $£ 6.5$ million taken up a year later both the effectiveness of the scheme and the industry's commitment to a significant

Table 1 Average fresh water demand and discharge of pollution from pulping and papermaking in Sweden, 1970-71

\begin{tabular}{|c|c|c|c|c|}
\hline \multirow{2}{*}{$\begin{array}{c}\text { Fresh water } \\
\text { demand } \\
\left(\mathrm{m}^{3} / \mathrm{m} \text { tonne }\right)\end{array}$} & \multirow[t]{2}{*}{$\mathrm{BOD}_{7}{ }^{1}$} & \multicolumn{2}{|c|}{$\begin{array}{c}\text { Water } \\
\text { pollution }\end{array}$} & \multirow{2}{*}{$\begin{array}{c}\text { Air } \\
\text { pollution } \\
\text { (kg/m tonne) }\end{array}$} \\
\hline & & Colour & Solids & \\
\hline 250 & 50 & 210 & 30 & 20 \\
\hline 375 & 90 & 85 & 40 & 50 \\
\hline 50 & 15 & - & 20 & 0 \\
\hline 130 & - & - & 50 & 0 \\
\hline
\end{tabular}

Sulphite pulping

Mechanical pulping ${ }^{4}$

Papermaking

expansion of recycling are open to question.

The dominant problem in discussions of waste paper recycling concerns its collection. Potentially the waste paper is there, as Britain currently recycles only $27 \%$ of its total consumption. But instability in the market has severely weakened the collection network.

To overcome this problem, much of the effort has been focused, unsuccessfully, on stabilising the market. The tasks of building up the capacity to recycle and changing attitudes to paper quality are as important. Indeed, the strong interdependence of these three factors means they must be tackled together.

${ }^{1}$ Discharge of organic matter is measured by Biological Oxygen Demand $\left(\mathrm{BOD}_{7}\right.$ in $\mathrm{kg} / \mathrm{tonn}^{\mathrm{e}}$ product) and colour (platinum units in $\mathrm{kg} /$ tonne product). Figures include contributions from accidental discharges.

${ }^{2}$ Sulphur emissions calculated as sulphur dioxide. Sulphur emissions from oil-fired boilers not included.

${ }^{3}$ Bleached softwood.

${ }_{4}$ Unbleached stone groundwood.

Source: "Pollution Control in the Swedish Pulp and Paper Industry", H. Norrstrom, Ambio, 4, No. 2, 1975.

Table 2 Environmental impact comparison for 1,000 tonnes of pulp

\begin{tabular}{|c|c|c|c|}
\hline \multicolumn{2}{|c|}{$\begin{array}{l}\text { Low grade paper } \\
\text { unbleached }\end{array}$} & \multicolumn{2}{|c|}{ Bleached pulp } \\
\hline $\begin{array}{l}\text { unbleached } \\
\text { virgin kraft } \\
\text { pulp }\end{array}$ & $\begin{array}{l}\text { recycled } \\
\text { fibre }\end{array}$ & $\begin{array}{c}\text { bleached } \\
\text { virgin kraft } \\
\text { pulp }\end{array}$ & $\begin{array}{l}\text { deinked } \\
\text { recycled } \\
\text { fibres }\end{array}$ \\
\hline $\begin{array}{c}100 \times 10^{8} 1 \\
17 \times 10^{12} \mathrm{~J} \\
42 \mathrm{t}\end{array}$ & $\begin{array}{c}42 \times 10^{6} \mathrm{l} \\
5 \times 10^{12} \mathrm{~J} \\
11 \mathrm{t}\end{array}$ & $\begin{array}{c}195 \times 10^{6} 1 \\
25 \times 10^{12} \mathrm{~J} \\
49 \mathrm{t}\end{array}$ & $\begin{array}{c}16610 \times \times^{6} \mathrm{l} \\
9 \times 10^{12} \mathrm{~J} \\
20 \mathrm{t}\end{array}$ \\
\hline $15 \mathrm{t}$ & $9 t$ & $23 \mathrm{t}$ & $20 \mathrm{t}$ \\
\hline $8 \mathbf{t}$ & $6 \mathrm{t}$ & $24 \mathrm{t}$ & $77 \mathrm{t}$ \\
\hline
\end{tabular}

Process water use

Energy consumption

Air pollutants

Waterborne wastes emitted (BOD)

Waterborne wastes emitted (suspended solids)
Source: Grace and Turner, "Paper recycling and social policy", Resources Policy, Dec. 1976

\author{
Sorry, for copyright \\ reasons some images \\ on this page may not \\ be available online
}

